\title{
咬傷（イヌ）による咽頭，食道損傷の一例
}

\author{
山本一 博, 松 岡 明 裕 \\ 稲木 勝 英，古川 浩三
}

\section{Trauma for a Dog Bite in the Pharyngo-esophagial Region; A Case Report}

Kazuhiro Yamamoto, M.D., Akihiro Matsuoka, M.D., Katsuhide Inaki, M.D., and Kozo Furukawa, M.D.

Department of Otorhinolaryngology, Kitasato University School of Medicine, Sagamihara, Kanagawa

A patient with multiple injuries in the pharynx and esophagus caused by a dog bite was discussed. Examination showed two perforations in the digestive organs: One was located at the left pyriform sinus and the other in the wall of the cervical esophagus. The sternocleidmastoid muscle, anterior cervical muscle, internal jugular vein and sympathetic nerve trunk were also invaded by the trauma.

If an injury to the esophagus is suspected it is usually necessary that diagnosis and treatment be done as quickly as possible. In this case, a esophagial injury was diagnosed at an early stage, because saburras were found in the avulsed wound to the cervical skin. There is usually a high possibility of multiple wounds and more serious subcutaneous damage compared to size of a lesion on the surface of the skin in dog bite injuries, and it is indispensable to understand all existing wounds before beginning surgical treatment.

Key words : 頸部咬傷, 食道損傷, ゴールデンアワー

\section{I .はじめに}

異物や消化管内視鏡による外傷性食道損傷の 報告は散見される。しかし，それ以外の原因に よる食道損傷の症例は少ない。これらの報 告1 19) を見ると損傷部位では中部，下部食道が 殆どを占め，さらに原因の多くは交通外傷等に 伴う強腹部打撲による圧挫である。今回われわ れは, 咬傷（イヌ）による咽頭, 頸部食道損傷 の一例を経験したので，若干の考察を加えて報 告する。

北里大学病院耳鼻咽喉科

別刷請求： $=228$ 神奈川県相模原市北里 1-15-1 北里大学病院耳鼻咽喉科 山本一博

投稿受付：1994年 1月26日

\section{II . 症 例}

患 者：6歳，女児

初 診: 1991年 2 月 2 日

主 訴：イヌによる頸部咬傷

現病歴：1991年 2 月 2 日，公園で秋田犬（飼 犬に手を出したところ，突然頸部を嚙まれた。 直ちに近医に搬送されたが，ショック状態，お よび呼吸不全が認められたため, 気管切開術が 行われた。また一部の創からの出血に対して縫 合が行われた。さらに視診上，頸部裂創部より 食物残渣の流出が認められ，食道ファイバーに よる内視鏡検査が施行された。その結果，食道 入口部直下に著明な発赤が見られ，食道損傷疑 いにて受傷当日に当院救命救急センターを受診 した。 
既往歴：特記すべきことなし

家族歴：特記すべきことなし

現 症：来院時意識清明, 体温 37.3 度, 血圧 $133 / 87 \mathrm{mmHg}$, 呼吸数34回/分, 脈拍155回/分で あった。図 1 のごとく, 左頸部を中心に多数の 創が認められた。また創の一部より食物残渣の 流出が見られた。

\section{臨床検査成績}

〈血液検查成績〉白血球数と CPK の上昇が認 められた。白血球は炎症性, CPK は筋肉の挫滅 によるものと考えた（表 1 参照）。

〈画像診断〉(1)頸部単純レントゲン写真：皮下 気腫のほか，食道周囲に多数の free air 認め たが，縦隔気腫，胸水貯留，肺炎等の所見はな かった（図 2)。

(2)頸部 CT 所見：傍咽頭から肺尖部の高さに 至る深頸部に free air を認めた（図 3 )。

〈気管支〉ァイバー検査〉中咽頭から気管分岐 部まで観察したが，特に異常を認めなかった。

以上の所見より, 食道損傷および食物残渣に よる頸部広範囲の感染を考え, 緊急の創傷部の 洗浄術（デブリートメント）打よび裂創部縫合 術を施行した。

\section{手術所見}

手術は全身麻酔下で行った。まず裂創の箇所 と数を確認するため硬性食道鏡を施行した。左 梨状窩の外側寄りに直径約 $8 \mathrm{~mm}$ の瘻孔を認 めた。周囲は発赤し白苔が付着していた。また

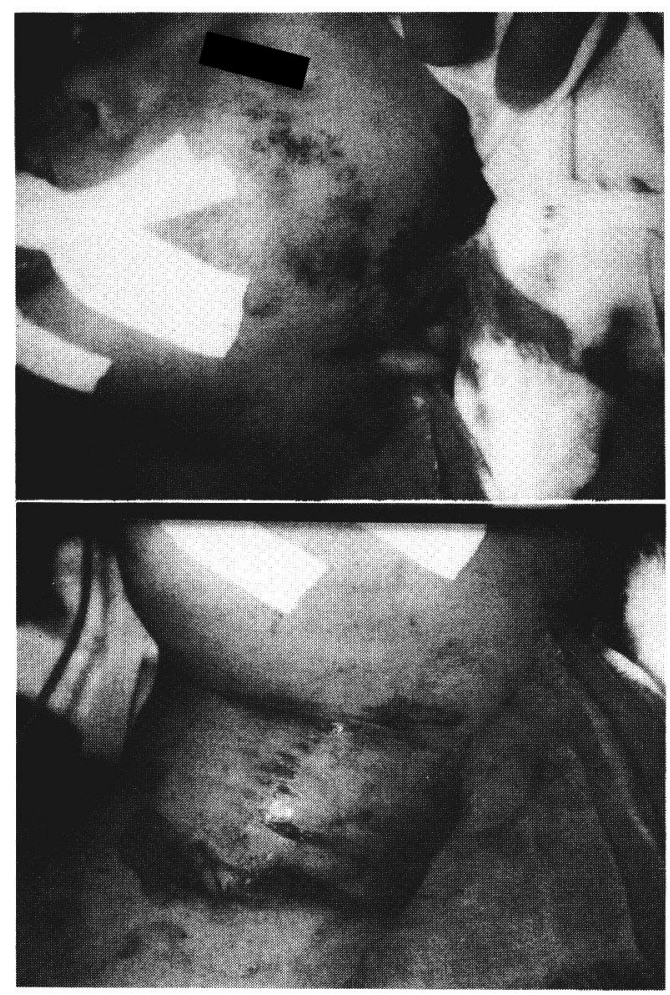

図 1 来院時頸部所見

食道入口部より $2 \mathrm{~cm}$ 肛側に (門歯より $17 \mathrm{~cm}$ ) 長さ約 $2 \mathrm{~cm}$ の瘦孔があり，周囲には白苔が付 着し，淡赤色の液体抢よび食物残渣の流出を認 めた。他に異常は認めなかった。

表 1 血液検查成績

\begin{tabular}{|c|c|c|c|c|c|}
\hline \multicolumn{2}{|c|}{ 血液一般検査 } & \multicolumn{4}{|c|}{ 血液生化学検査 } \\
\hline 項目 & 結果 & 項目 & 結果 & 項目 & 結果 \\
\hline WBC & $16,900 / \mu 1$ & T.P & $5.2 \mathrm{~g} / \mathrm{dl}$ & $\mathrm{Na}$ & $141 \mathrm{mEq} / 1$ \\
\hline $\mathrm{RBC}$ & $3.58 \times 10^{6} / \mu 1$ & T. B & $0.4 \mathrm{mg} / \mathrm{dl}$ & $\mathrm{K}$ & $4.2 \mathrm{mEq} / 1$ \\
\hline $\mathrm{Ht}$ & $31.2 \%$ & GOT & $49 \mathrm{IU} / 1$ & $\mathrm{Cl}$ & $107 \mathrm{mEq} / 1$ \\
\hline $\mathrm{Hb}$ & $10.5 \mathrm{~g} / \mathrm{dl}$ & GPT & $14 \mathrm{IU} / 1$ & $\mathrm{Ca}$ & $8.6 \mathrm{mg} / \mathrm{dl}$ \\
\hline PLT & $42.5 \times 10^{4} / \mu 1$ & $\mathrm{LDH}$ & $521 \mathrm{IU} / 1$ & $\mathrm{P}$ & $5.3 \mathrm{mg} / \mathrm{dl}$ \\
\hline & & $\begin{array}{l}\text { CPK } \\
\text { AMY }\end{array}$ & $\begin{array}{r}1258 \mathrm{IU} \\
210 \mathrm{IU}\end{array}$ & GLU & $169 \mathrm{mg} / \mathrm{dl}$ \\
\hline & & BUN & $17 \mathrm{mg} / \mathrm{dl}$ & & \\
\hline & & $\mathrm{Cr}$ & $0.5 \mathrm{mg} / \mathrm{dl}$ & & \\
\hline & & UA & $5.2 \mathrm{mg} / \mathrm{dl}$ & & \\
\hline
\end{tabular}




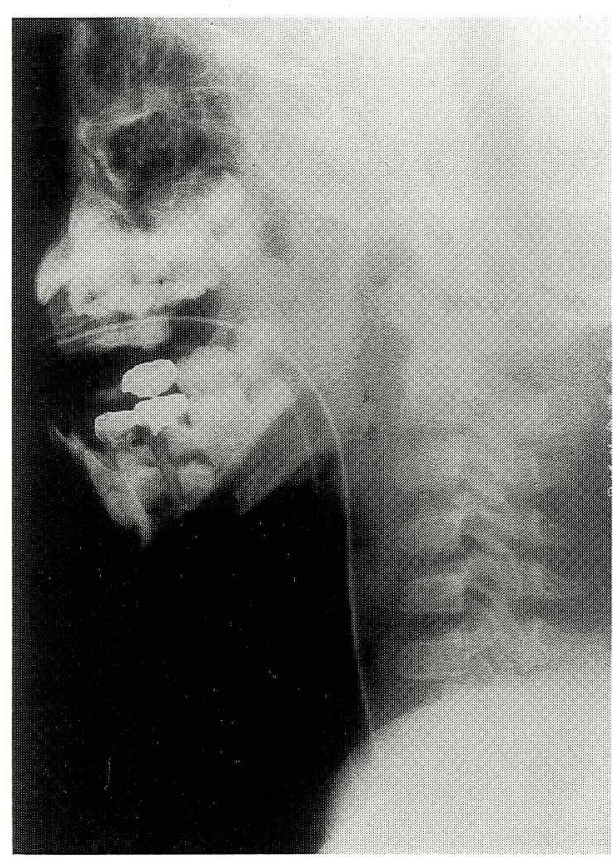

図 2 頸部単純レントゲン写真

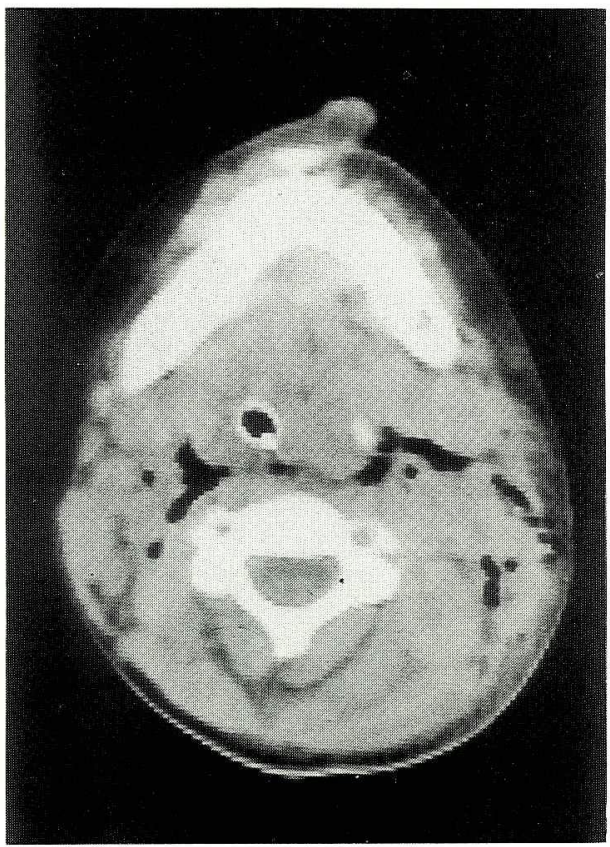

図 3 頸部 C T写真

皮膚切開は皮膚咬傷創を利用して，側切開に 準じて行った。図 4 に手術時所見を示す。食物 残渣咬傷により生じたと思われる組織の離開部 に貯留していた。その上方は傍咽頭上部で，そ
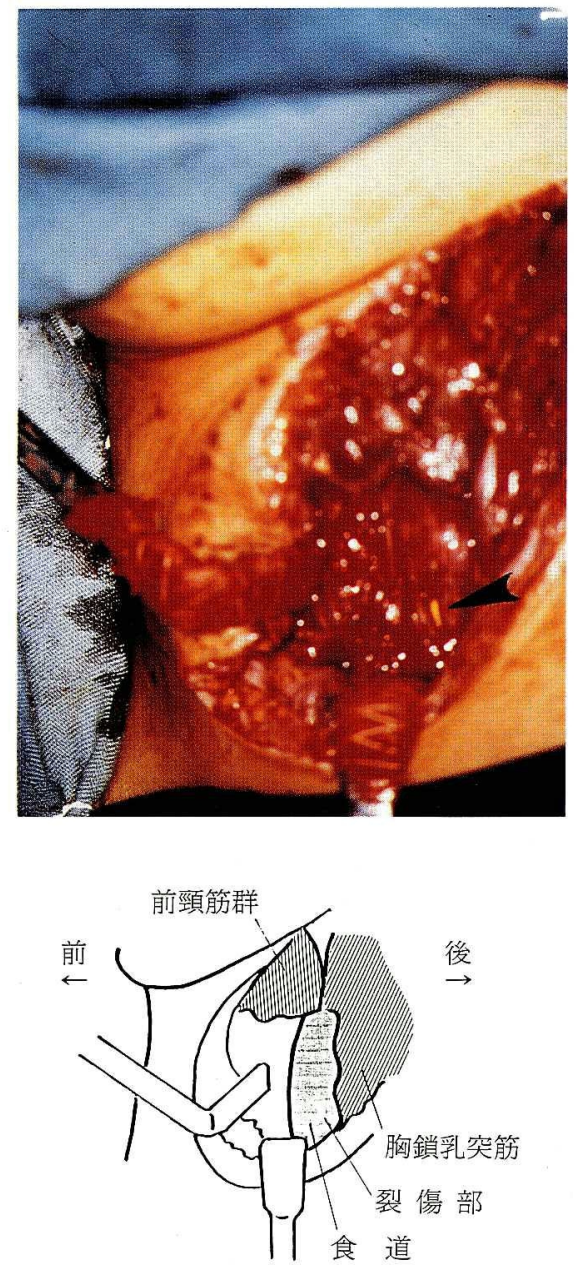

図4 手術時頸部所見

の外側方は僧帽筋内側縁まで認められた。咬傷 により，胸鎖乳突筋は下方 $1 / 3$ の高さで，その前 方 $1 / 2 \sim 1 / 3 の$ 切断が認められた。また前頸筋群 の一部も切断されていた。さらに食道の裂創部 位を明視下に置くため胸鎖乳突筋の前縁を剝離 したが，この際血腫が認められ，これを除去す ると内頸静脈からの出血であることが確認され た。甲状咽頭筋を切断し, 左梨状窩の約 $1 \mathrm{~cm}$ の 裂創部を確認し，縫合閉鎖した。また頸部食道 の損傷部位は図 4 に示すごとく第三気管軟骨か ら第五気管軟骨にかけて, 食道左側壁に約 $2 \mathrm{~cm}$ の大きさで見られ，これを縫合閉鎖した。食物 残渣による創の污染を除くため, 十分な量の抗 生剂 (Cephaloridine) で洗浄し，持続吸引ドレ ーンを留置して手術を終了した。 


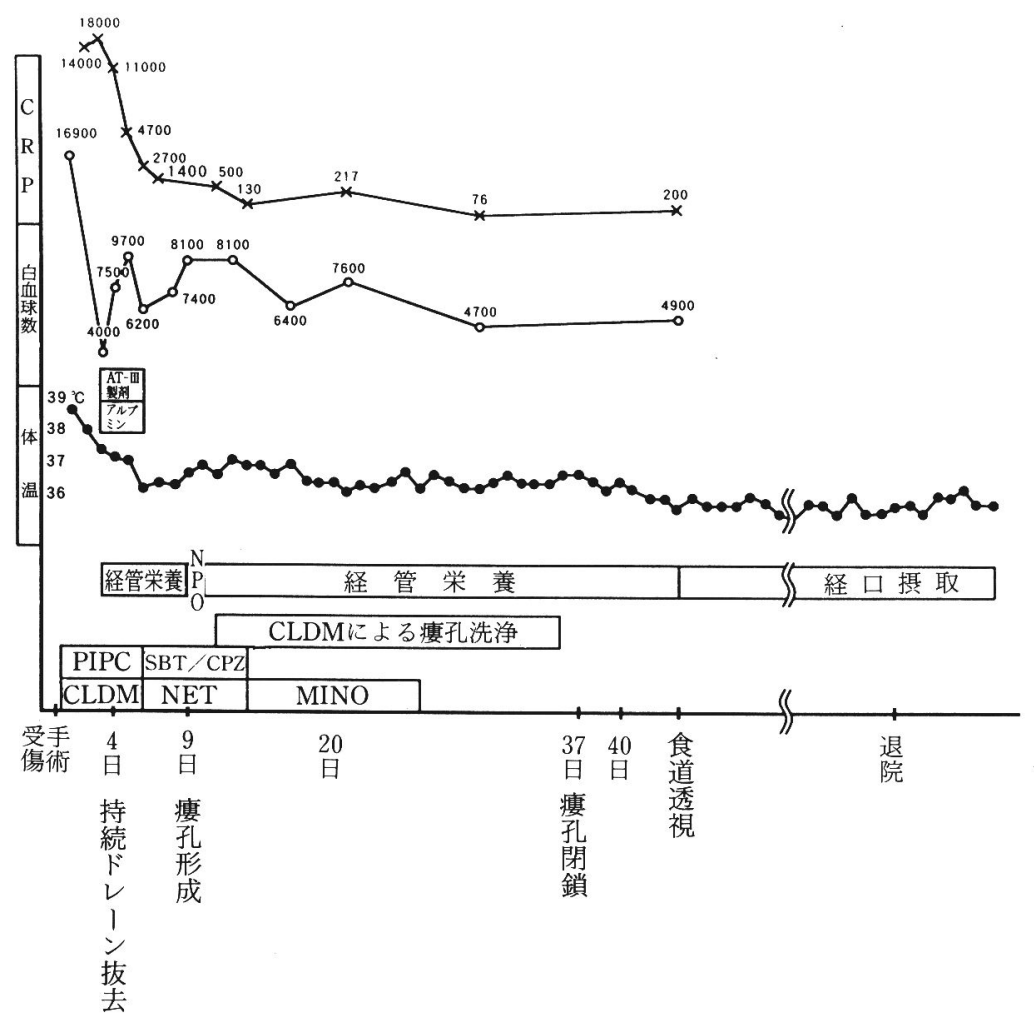

図 5 術後経過

\section{術後経過（図 5 ）}

術後は，抗生剤の全身投与と裂創 縫合部位の安静および清潔を守るた め, 胃管による栄養管理を行った。 その結果, 順調な炎症反応の低下を 認め, 術後 4 日目に頸部の持続吸引 ドレーンを抜去した。しかしその後, 炎症反応の上昇および一部の皮膚の 発赤を認め, 術後 9 日目に咽頭皮膚 瘦の形成をみた。癭孔は直径数 $\mathrm{mm}$ の小さなもので, 保存的治療による 閉鎖が期待できたため, 禁食下で創 部を圧迫し経過観察した。その結果, 術後37日目に咽頭皮膚瘦の閉鎖を認 めた。閉鎖後の咽頭食道造影では, 瘢痕収縮のためか頸部食道の狭窄を 認めたが，バリウムの漏出や貯留お

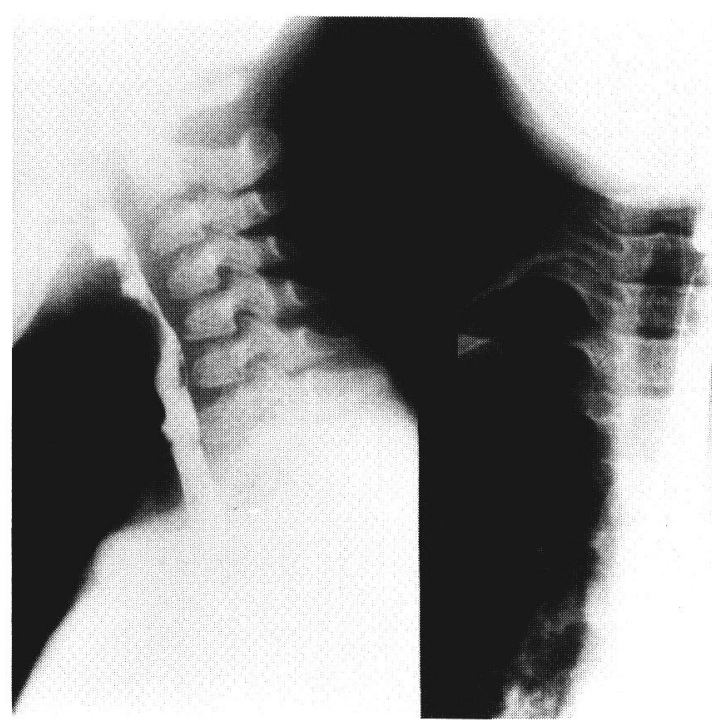

図 6 食道造影
よび誤嚥等の所見はみられなかった(図 6)。経 口摄取を開始したが，誤嚥や炎症反応の上昇は なく, 術後66日目に退院した。後遺症として左
ホルネル症候群を認める以外, 発声, 構音およ び與下機能に異常を認めなかった。 
表 2 本邦における食道損傷報告例

\begin{tabular}{|c|c|c|c|c|c|c|c|c|}
\hline 症例 & 報告者 & 報告年 & 年齢 & 性 & 発 生 機 序 & 破裂部位 & 治 & 転帰 \\
\hline 1 & 斉藤ら & 1960 & 14 & 女 & ボールによる腹部打撲 & 中部 & 縫合閉鎖 & 治癒 \\
\hline 2 & 中山ら & 1972 & 44 & 男 & ボンベ爆発 & 不明 & 胃瘻造設 & 死亡 \\
\hline 3 & 橋本ら & 1973 & 23 & 男 & 交通事故による胸部打撲 & 中部 & 縫合閉鎖 & 治癒 \\
\hline 4 & 由良ら & 1973 & 25 & 男 & クレーンによる胸部打撲 & 中部 & 縫合閉鎖 & 治癒 \\
\hline 5 & 大迫ら & 1977 & 31 & 男 & 日本刀による刺創 & 不明 & 食道切除 & 治癒 \\
\hline 6 & 岡安ら & 1978 & 47 & 男 & タイヤ爆発 & 中部 & 開胸ドレナージ & 治癒 \\
\hline 7 & 田村ら & 1981 & 37 & 男 & 木片による胸部打撲 & 中部 & 経皮ドレナージ & 治癒 \\
\hline 8 & 鈴木ら & 1984 & 16 & 男 & 交通事故による頸部打撲 & 頸部 & 食道再建 & 治癒 \\
\hline 9 & 土山ら & 1985 & 24 & 男 & ショベルカーによる腹部打撲 & 下部 & $\mathrm{T}$-tube 挿入 & 治癒 \\
\hline 10 & 土山ら & 1985 & 9 & 男 & 交通事故による腹部打撲 & 下部 & 開胸ドレナージ & 治癒 \\
\hline 11 & 田中ら & 1986 & 19 & 男 & 交通事故による頸部打撲 & 頸部 & 縫合閉鎖 & 治癒 \\
\hline 12 & 高橋ら & 1986 & 22 & 男 & 交通事故による胸部打撲 & 中部 & 縫合閉鎖 & 治癒 \\
\hline 13 & 大槻ら & 1987 & 20 & 男 & 交通事故による胸部打撲 & 下部 & 胸部食道全摘 & 治癒 \\
\hline 14 & 藤崎ら & 1987 & 55 & 男 & 自殺による頸部刺創 & 頸部 & 縫合閉鎖 & 治癒 \\
\hline 15 & 藤崎ら & 1987 & 1 & 女 & 歯ブラシによる刺創 & 咽頭, 頸部 & 縫合閉鎖 & 治癒 \\
\hline 16 & 藤崎ら & 1987 & 3 & 女 & 歯ブラシによる刺創 & 咽頭, 頸部 & 縫合閉鎖 & 治癒 \\
\hline 17 & 大友ら & 1988 & 1 & 女 & 歯ブラシによる刺創 & 梨状窩 & 縫合閉鎖 & 治癒 \\
\hline 18 & 林ら & 1988 & 18 & 男 & 交通事故による胸部打撲 & 下部 & 縫合閉鎖 & 治癒 \\
\hline 19 & 山本ら & 1991 & 6 & 女 & イヌによる頸部咬傷 & 咽頭, 頸部 & 縫合閉鎖 & 治癒 \\
\hline
\end{tabular}

\section{III. 考 察}

医原性（内視鏡など）や異物に起因しない外 傷性食道損傷の1960年から1988年までの私ども が検索しえた報告例を表 2 に示す。頸部，上部 食道損傷の報告は 3 例のみに見られ ${ }^{8,11)}$, しかも 発生機序に動物が媒体であるものは今回の検索 ではみられなかった。外傷性食道損傷の発生機 序を土山ら 11 は次のように分類している。

1) 穿通性損傷, 2) 圧挫による損傷, 3) 食道内 圧上昇による圧外傷：(a)高気圧体の流入，(b)急 激な腹腔内圧の上昇により引き起こされる食道 内圧の上昇。

上記の中でも穿通性損傷を発生機序とする症 例は非常に少なく, 例えば日本刀による刺創 ${ }^{9}$, 自殺による頸部刺創 ${ }^{8}$, 歯ブラシによる小児の 外傷8)など数例のみであった。自験例の場合, 鋭 利なイヌの歯により損傷されたもので, 土山の 分類上では 1 に入る。このような動物の咬傷に よる食道損傷の特殊性として，1）多発裂創の可 能性，2)深い創となることがある，3)不潔な歯
による感染の助長, などが挙げられる。 咬傷は通常複数の歯によりもたらされ，しか も受傷に際して強い力が小さな点に集中するた め, 結果として上記の $1 ， 2$ のような創を生じ る。さらに咬むという動作は実に複雑で, さま ざまな方向に力が加わり，また組織にずれを生 じさせながら損傷をもたらす。特に動物の場合 は，咬むというより咬みちぎるというほうが妥 当であり, 上記にあげた受傷機転はより顕著に なる。ゆえに刃物による刺創など単一, かつ直 線的なべクトルで表現される穿通性損傷とは受 傷機転が全く異なるし, 機序がより複雑なため, 受傷程度もより重篤になる可能性が高いといえ る。現に自験例の手術所見を見ても，創は複数 であり，形態的には刺創というよりはむしろ裂 創であった。周囲の挫滅もひどく，また内頸静 脈や, 交感神経幹が直接損傷をうけるほど深い ものであった。皮膚表面の視診から予想された 皮下損傷より重篤な手術所見であった。

術前検査の方法としては食道透視や内視鏡検 査が行われているのが現状である。両者に関し 
ては一長一短があり，特に内視鏡検査は創を拡 大したり新たな創を形成する恐れがあるので安 易に行うべきでないという意見もある。

しかし自験例では，(1)患者が円滑に造影剤を 嚥下できる状態ではなかったこと，(2)食道造影 では食道内の食物残渣が造影剂とともに周囲組 織へ流出する危険があったこと，(3)創の形態を 直視できるので，その部位や大きさの確診がで きること，(4)下咽頭，上部食道の専門家である 耳鼻咽喉科医が施行したこと，等の有効性を考 慮し，硬性食道鏡を施行した。その結果，二力 所の創を術前に確認することができ，円滑な手 術操作を行えた。

3 の不潔な歯による感染の助長に関しては, 受傷から治療開始までの時間，いわゆるゴール デンアワー内での処置が重要であるとされてい る。ゴールデンアワーを越えた場合, 一次的縫 合閉鎖を行っても縫合不全を起こしたり，特に 重症例では膿胸や敗血症を合併し, 致命的にな る可能性が高い。しかしその具体的な時間につ いては文献によりまちまちで，6２4時間の幅 があった。自験例では受傷から手術開始まで約 8 時間であり, 処置は比較的早急であったとい える。

しかし術後縫合不全から咽頭皮膚瘦を形成し た。その理由として, (1)頸部の挫滅が重篤で嘔 吐に伴う食物残渣の流出により周囲に強い炎症 がもたらされたこと, (2)創が深部にまで達して いたため, 食物残渣による污染の範囲が広く, 完全にデブリートメントができなかったこと， (3)不潔なイ又の歯が直接損傷をもたらしたこと により, 局所の炎症が助長されたこと, 等があ げられる。一般に頸部, 上部食道の小穿孔では 強力な保存的治療により治癒に至る例もある。

しかし上記にあげた特殊性, および受傷機転 を考慮すれば，咬傷の場合受傷からの経過時間 にかかわらず，何らかの観血的処置を行うべき であると考えられる。しかし受傷初期は症状, 所見に乏しいことが多く, また重篤な損傷の場 合には同時に縦隔内や頸部の重要藏器に致命的 損傷を伴うため, 発見が遅れることもある。

胸腹部に強い力のかかる外傷や, 深頸部に達 する刺創, さらに大型な動物による咬傷のよう な複雑な受傷機序を有する損傷などの際には,
食道損傷の可能性を常に考える必要がある。

\section{IV . まとめ}

咬傷（イヌ）による咽頭食道損傷の一例を報 告した。本症例の消化管損傷部位は左梨状窩と 頸部食道の 2 力所で胸鎖乳突筋, 前頸筋群, 内 頸静脈，交感神経幹の損傷を伴った。

食道損傷の可能性が少しでも疑われる場合に は, 早急な精査と処置が必要である。自験例で は皮膚裂創部から食物残渣の流出をみたことに より，早期に診断することができた。また咬傷 の場合創が多発したり，皮膚の視診より実際の 皮下損傷の方がより重篤である可能性が高く, 術前における創の把握が必要である。

\section{文献}

1）斉藤 寛, 梅園 明, 森末久雄・他：異常な経 過をたどった特発性食道破裂の 1 治験例。胸部 外科, $13: 45-52,1960$.

2 ) 中山 博, 大津 暁, 小沢弘有 - 他：特発性食 道破裂と思われる 1 治験例. 千葉医会誌，47： 259, 1972.

3 ）橋本昌武, 大梘 弘：外傷による気管食道㿉. 日外会誌, $74 ： 48,1973$.

4 ）由良二郎, 岡田英也, 吉田國二 ・他：外傷性気 管食道瘦の一例. 日外会誌, $74: 313,1973$.

5 ) 田中秀治, 中江純夫, 前村達・他：胸部外傷 を伴う穿通性気管，食道損傷の 2 例. 日本救急 医学界関東地方会雑誌， $7 ： 442-444,1986$.

6 ) 岡安健至, 森山 裕, 新里順勝-他：圧縮空気 (compressed air) による食道破裂の 1 例. 外科, 40:1505-1507, 1977.

7 ）土山雅人, 友田淳一, 石井完治・他：外傷性食 道破裂一自験例 2 例を含む本邦報告例の検討. 救急医学, 9:109-113, 1985.

8 ) 藤崎真人, 植松義和, 高田育明・他：頸部食道 損傷の 4 治験例. 日消外会誌, $20 ： 214,1987$.

9 ) 大迫 努, 佐藤 正, 藤尾 彰・他：食道損傷 について.関西医大誌, $29 ： 392,1977$.

10）杉町圭蔵，大野真司・他：食道穿孔。消化器科, $5: 588-595,1986$.

11）大友義行, 小口 学, 本橋俊和・他：歯みがき 中転倒し, 歯ブラシによって食道損傷後, 縦隔 炎を起こした 1 幼児例。 日小児会誌，92：215， 1987.

12）田村利和, 桑島耀夫, 河崎秀樹 - 他：純的外傷 による食道破裂の 1 治験例および過去 10 年間の 本邦報告例の集計. 救急医学, $5: 817-820,1971$.

13）中野 実, 増茂 仁，高橋利文・他：純的外傷 性食道破裂患者の管理. ICU と CCU, 13：945951, 1989. 
14）大梘鉄郎, 福谷明直, 柴田純祐 - 他：外傷性食 道破裂の一治験例. 臨外, 45：509-512, 1990.

15）鈴木定雄, 田中隆士, 平野忠弘 - 他：鈍的外傷 による頸部気管完全離断. 食道破裂の治験. 大 原年報, 27：115-119, 1984 .

16）安本良子, 丸川征四郎, 津田三郎・他：食道破 裂, 穿孔の診断と治療における問題点一自験例 9 例の分析に基づいて一. ICU と CCU, 12 ：
$885-891,1988$.

17）掛川暉夫：食道損傷の病態生理とその処置. 外 科, $36: 30,1974$.

18) Michel, L., et al. : Esophageal perforation. Ann. Thorac. Surg., $33: 204,1982$.

19) Wesdrop, I.C.E., Bartelsman, J.F.W.M., Huibregtse, $\mathrm{K}$, et al. : Treatment of instrumental oesophageal perforation. Gut, 25：398, 1984. 